\title{
The Research on the Measurement of Inefficiency Investment Degree of China's GEM Listed Companies
}

\author{
Huina $\operatorname{Tan}^{1}$ \\ ${ }^{1}$ School of Economics, Jinan University, Guangzhou, China \\ Correspondence: Huina Tan, School of Economics, Jinan University, Guangzhou 510632, China. Tel: \\ 86-136-6085-2785.
}

Received: March 14, 2017

Accepted: March 19, 2017

Online Published: March 22, 2017

doi:10.20849/ajsss.v2i1.130

URL: https://doi.org/10.20849/ajsss.v2i1.130

\begin{abstract}
October 30, 2009, the GEM officially launched, which was an important step to improve China's capital market system. For the listed companies, investment efficiency is one of the three major investment decisions. Due to the short period of study, the research area is less related to the GEM listed companies.

Theoretically, in the perfect market described by Modigliani and Miller, investment decisions are totally determined by investment opportunities, regardless of the impact of other factors. But in the real world of imperfections, agent problems and information asymmetry can lead to inefficient investment. From the point of view of the Principal-agent Theory and the Free Cash Flow hypothesis, the principal-agent conflict between the shareholders and the senior managers leads to the fact that the senior managers maximize their own utility and put the free cash flow into the project whose net present value is not greater than zero. In the information asymmetry theory and financing constraints hypothesis, the information asymmetry between the company and the external investors will make it difficult for external investors to make an accurate valuation of the company. To reduce the loss of the risk, they tend to underestimate the value of the company, so the financing cost of company in the capital market have been raised, and when the internal cash is in the shortage, the senior managers do not want to choose external financing with high cost to meet the investment need, to give up investment in project whose the net present value is larger than zero, resulting in underinvestment.

At the level of empirical analysis, this paper chose the financial data and market transaction data of the GEM listed companies from 2010 to 2015 to study. Based on the Expected Investment Model of Richardson (2006), this paper used the generalized difference moment method (GMM) to estimate the expected additional investment, with the amount of investment, resulting in overinvestment and underinvestment. The conclusion is that there are overinvestment behavior and underinvestment behavior of the GEM listed companies in the research period.

This paper measured the level of inefficient investment of listed companies on the GEM, so that the micro-subject in the multi-level capital market can clearly define the direction of its own need. In addition, we also hope to provide empirical reference for the policy makers in the formulation of relevant policies to create a good market environment for listed companies.
\end{abstract}

Keywords: GEM Listed Companies, Inefficient Investment, Expected Investment Model

\section{Introduction}

October 30, 2009, China's formal establishment of the GEM, made the construction of the multi-level capital market system have improvement. Compared to the Shanghai and Shenzhen motherboards, small and medium-sized board, the most important function of the GEM is to provide financing and transactions for the high potential start-up technology companies. The research angle of this paper is to measure the degree of inefficient investment of the GEM listed companies. Inefficient investment means that when an investment decision deviates from the maximization of the firm, the senior manager invests in a project with a net present value of less than zero (overinvestment) or gives up a project with a net present value greater than zero (underinvestment).

In theory, the study of inefficient investment is mainly focused on two aspects. On the one hand, to explore the causes of inefficient investment, from the angles of the concept of Principal-agent Theory (Jensen and Meckling, 
1976), the perspective of Free Cash Flow Hypothesis (Richardson, 2006; Yu Honghai et al., 2010), the concept of Information Asymmetry Theory (Myers and Majluf, 1984; Wang Song, 2011), the perspective of Financing Constraints Hypothesis (Fazzari et al., 1988; Kaplan And Zingales, 1997). On the other hand, it is the measure of inefficient investment. There are three widely used models, which are the investment-cash flow sensitivity analysis model based on the Tobin Q model (Fazzari, Hubbard and Petersen, 1988), Vogt model based on cash flow, sales revenue and Tobin Q (Vogt, 1994) and the Richardson residual measure model using the model residuals to measure the overinvestment and underinvestment (Richardson, 2006).

In fact, investment decision-making has been the core of the company's investment process. As the high-tech company incubator platform, the establishment of the GEM was not long and its listed companies have different degrees of inefficient investment behavior. This paper makes an empirical study on the inefficient investment level of listed companies on the GEM to lay the foundation for improving the investment efficiency of listed companies on the GEM, so that the micro-subject in the multi-level capital market can clearly define the direction of its own need. In addition, we also hope to provide empirical reference for the policy makers in the formulation of relevant policies to create a good market environment for listed companies.

Specifically, this article is to answer the following questions: First, what causes inefficient investment behavior of the GEM listed companies? Second, how to measure the extent of inefficient investment in listed companies on the GEM? The main body of the article is divided into five parts, summarized as follows:

The first chapter is the overall description of the study, including the meaning and content of this article, the method used.

The second chapter reviews the four related theories and literatures of Principal-agent Theory, Free Cash Flow Hypothesis, Information Asymmetry Theory and Financing Constraint Hypothesis, providing theoretical basis for empirical analysis.

The third chapter is the research design, on the basis of theoretical review and literature review, gives the explanations of the variables involved and the model construction process.

The fourth chapter is the empirical analysis, and the Expected Investment Model is used to measure the difference between the expected investment and the actual investment of the GEM listed companies.

The fifth chapter is the conclusion and the prospect, using the theoretical and the empirical analysis, draws the corresponding conclusion, and carries on the prospect to the future research.

\section{Theoretical Review and Literature Review}

\subsection{Principal-agent Theory}

Principal-agent theory, as a logical starting point for modern corporate governance, was proposed by American economists Berle and Means in 1932. The theory believes that the owners of the company, only to retain the remaining claims, and give out the right to operate the business, is a way to promote the company's professional management and long-term development.

Principal-agent theory holds that the emergence of principal-agent relationship is the inevitable result of the continuous development of productive forces and the social division of labor. The reason is that the continuous development of productive forces, making the division of labor more and more specific, the owner may lack the appropriate knowledge, skills and time so that rights cannot be realized by their own. At the same time, the social division of labor makes professional agents have the appropriate knowledge, skills and time, can be entrusted with the realization of rights. The requirements of professional management are getting higher and higher in modern companies. The owner of the company will deliver the rights to the agent through the contract, and provide incentives and other incentives for the agent. However, the client and the agent's utility function are not consistent. However, their goals are not the same, resulting the agency conflict. If there is no effective mechanism to arrange, then the agent has the motivation to maximize the utility of their own at the expense of the client's max utility, which will deviate from the basic purpose client establish the contract. Therefore, the principal-agent theory mainly studies how to design the best contract to motivate manager to maximize the interests of the client in the case of agency conflict.

In the case of the separation of general ownership and management rights of modern listed companies, the shareholders who are holders of ownership are largely unable to intervene in corporate governance. As a senior manager, through the contract given by the decision-making power and become the actual controller of the company. Under the premise of the pursuit of different maximization, senior managers will make their own interests and make a company development plan that is not conducive to the interests of shareholders. This is 
reflected in the inefficient investment in the field of corporate investment. Therefore, the principal-agent conflict between the shareholders of the GEM listed companies and the senior manager may lead to the company's inefficient investment behavior.

\subsection{Free Cash Flow Hypothesis}

The Free Cash Flow Hypothesis, which was derived from agency issues, was presented by Jensen in 1986. Free cash flow refers to the remaining cash flow that the company places on the cash held by all the items whose net present value is greater than zero. Due to the existence of agency problems, the profit maximization goal of shareholders and senior managers are not consistent with the long term, then the senior managers have the motivation to maximize their profits, regardless of the interests of shareholders, resulting in irrationally use free cash flow. So, Jensen believes that if shareholders can fully hold free cash flow will be able to limit the rights of senior managers to some extent, thereby reduce the cost of agents to ease the agency conflict.

If the shareholders cannot grasp the free cash flow, then this part of free cash flow within the company will be used by senior managers. In order to promote the development of performance and reflect the value of their own existence, senior managers tend to invest, since all projects with net present value greater than zero have been invested, then follow-up investment often means that the net present value of investment target is less than zero, leading to the company's overinvestment behavior. In the empirical study of this hypothesis, most scholars recognize that companies with large free cash flow are more likely to overinvest.

\subsection{Information Asymmetry Theory}

Mastering the complete information is a basic assumption of classical economics for economic people, but in real life, all market participants can not completely occupy the market information, information asymmetry arising from this. G.Akerlof (1970), M.Spence (1973), J E. Stiglitz (1981) studied the effects of information asymmetry from three different areas of commodity trading, labor and financial markets. The theory shows that in the information market, all market participants, because they have different resources, so obtain the information from different ways. All participants have the incentive to obtain more information in order to obtain more benefits and to avoid more risks, which leads to the fact that the party with more information is profitable by passing information to the party with less information. Therefore, information economics believes that information asymmetry will cause the unbalanced interests of market participants.

The asymmetry of information between the company and the outside investor can make it difficult for the outside investor to make an accurate valuation of the company. In order to reduce the risk of loss, it tends to underestimate the value of the company so that the financing costs of company in the capital market is raised, and when the internal cash is in the shortage, the senior managers do not want to choose external financing with high cost to meet the investment needs, to give up investment in projects whose the net present value is larger than zero, resulting in insufficient investment. If there is a higher valuation of external investors, the company will have too much free cash flow, to promote excessive investment behavior. So the company's information asymmetry in the external investors may lead to the company's inefficient investment behavior.

\subsection{Financing Constraint Hypothesis}

The concept of financing constraints, the earliest put forward by Fazzari, Hubbard and Petersen in 1988 based on the capital market information asymmetry, and the theory of optimal order financing. If the capital market is perfectly competitive, the company's internal financing and external financing can replace each other, then the company's investment decision-making and financing are independent of each other, so the amount of investment depends entirely on investment opportunities, and not be influenced by the financing of the way. However, in the real economy, the capital market is not completely competitive market, due to information asymmetry, transaction costs and other factors exist, the company's internal financing and external financing cannot completely replace each other, financing will affect the investment decision-making.

Relative to external financing, the internal financing has the advantage of lower cost, is the company's preferred way of financing, but it has premise that the company has surplus cash flow. When the current offer is not established, the internal financing is difficult to achieve, then turned to external financing. External financing is based on information asymmetry between the company and the investor, and it is difficult for the capital market to distinguish the quality of the company and to set interest rates in accordance with the average level of all companies, which leads to a better-performing company than above bear higher cost to get financing. High transaction costs become the reason for restoring the company's further investment. From the above analysis we can see that when there is a cash gap, while difficult to obtain external financing, investment will be subject to financing constraints. In 1984, Myers and Majluf argued that the cost of raising external funds was often higher 
than the cost of using internal funds due to the asymmetry of information. Therefore, in order to meet the needs of future investment, the company should maintain a certain cash flow. Therefore, the lack of free cash flow of the company, due to financial constraints, more prone to underinvest.

\section{Research Design}

\subsection{Data Sources and Sample Selection}

Based on the accuracy and availability of data, this paper selected the data of the GEM listed companies from 2010 to 2015 and screened them according to the following criteria: (1) By removing the samples listed in the study year, for the calculation needing to use the previous year's financial data and market transactions data; (2) excluding the financial and insurance industry, the real estate industry and incomplete data companies. The final sample involved 408 listed companies, a total of 2030 observations. The financial data and market transaction data used in the study are from the CSMAR database. This paper uses Excel and Stata software for data processing and empirical analysis.

\subsection{Model Design and Variable Definition}

In the field of investment, there are many literatures that study the determinants of the firm's investment level (Hubbard, 1998; Stein, 2003). Based on these, combined with Richardson (2006) model to form the Expected Investment Model. By using GMM to get estimation of new investment, combined with the normal amount of investment, the amount of overinvestment and underinvestment can be calculated. The formula is as follows:

$$
\begin{aligned}
\mathrm{I}_{\mathrm{i}, \mathrm{t}} & =\mathrm{a}_{0}+\mathrm{a}_{1} \text { Growth }_{\mathrm{i}, \mathrm{t}-1}+\mathrm{a}_{2} \operatorname{Lev}_{\mathrm{i}, \mathrm{t}-1}+\mathrm{a}_{3} \operatorname{Cash}_{\mathrm{I}, \mathrm{t}-1}+\mathrm{a}_{4} \mathrm{Age}_{\mathrm{I}, \mathrm{t}-1}+\mathrm{a}_{5} \operatorname{Size}_{\mathrm{i}, \mathrm{t}-1}+\mathrm{a}_{6} \operatorname{Ret}_{\mathrm{i}, \mathrm{t}-1} \\
& +\mathrm{a}_{7} \mathrm{I}_{\mathrm{i}, \mathrm{t}-1}+\text { Industry Dummy }+ \text { Year Dummy }+\varepsilon_{\mathrm{i}, \mathrm{t}}
\end{aligned}
$$

In the above model, $I_{i, t}$ is company $i$ 's new investment in year $t$, Growth $_{i, t-1}$ is the growth opportunity of company $i$ at the beginning of year $t, \operatorname{Lev}_{i, t-1}$ is the asset liability of company $i$ at the beginning of year $t, \operatorname{Cash}_{i, t-1}$ is the cash holding amount of company $i$ at the beginning of year $t$, Age $_{i, t-1}$ is the year of listing of company $i$ until the beginning of year $t$, Size $_{i, t-1}$ is company i's size of the assets at beginning of year $t$, Ret $_{i, t-1}$ for the company i's net asset yield at the beginning of year $t, I_{i, t-1}$ is company i's new investment in year $t-1$. Industry Dummy, Year dummy are variable for control the influence from the industry and year, $\varepsilon_{\mathrm{i}, \mathrm{t}}$ is the error adjustment. Expected Investment Model residuals for the actual amount of new investment minus the expected new investment, if it is positive, it means that overinvestment, with $\mathrm{OI}_{\mathrm{i}, \mathrm{t}}$ represents; if it is negative, it indicates lack of investment, with the $\mathrm{UI}_{\mathrm{i}, \mathrm{t}}$ represents.

\section{Empirical Analysis of the Expected Investment Model}

\subsection{Descriptive Statistics of Variables}

First, descriptive statistics are made for the variables in the Expected Investment Model. The results are shown in Table 1.

Table 1. Descriptive statistics of the Expected Investment Model

\begin{tabular}{cccccc}
\hline Variable name & $\begin{array}{c}\text { Number of } \\
\text { sample }\end{array}$ & Average value & $\begin{array}{c}\text { Minimum } \\
\text { value }\end{array}$ & $\begin{array}{c}\text { Maximum } \\
\text { value }\end{array}$ & $\begin{array}{c}\text { Standard } \\
\text { deviation }\end{array}$ \\
\hline $\mathrm{I}_{\mathrm{i}, \mathrm{t}}$ & 408 & 0.232 & 0.002 & 0.883 & 0.149 \\
Growth $_{\mathrm{i}, \mathrm{t}-1}$ & 408 & 0.437 & -8.359 & 17.509 & 1.024 \\
Lev $_{\mathrm{i}, \mathrm{t}-1}$ & 408 & 0.227 & 0.011 & 0.886 & 0.153 \\
$\mathrm{Cash}_{\mathrm{i}, \mathrm{t}-1}$ & 408 & 0.351 & -0.165 & 0.925 & 0.215 \\
$\mathrm{Age}_{\mathrm{i}, \mathrm{t}-1}$ & 408 & 2.610 & 0.000 & 6.000 & 1.482 \\
Size $_{\mathrm{i}, \mathrm{t}-1}$ & 408 & 20.824 & 18.679 & 23.154 & 0.631 \\
Ret $_{\mathrm{i}, \mathrm{t}-1}$ & 408 & 0.273 & -0.715 & 4.027 & 0.625 \\
$\mathrm{I}_{\mathrm{i}, \mathrm{t}-\mathrm{l}}$ & 408 & 0.228 & 0.002 & 0.883 & 0.150 \\
\hline
\end{tabular}

As shown in Table 1, the average annual investment of GEM listed companies from 2010 to 2015 is $23.2 \%$ of the total assets. All companies are in the stage of upgrading the investment level, but there are some differences in the investment level of different companies; the company's growth opportunities fall within a long positive 
and negative range, the standard deviation of 1.024, indicating that some companies show a high growth trend, some companies show lower or even negative growth trend. And between different companies, the company's asset-liability ratio fell between $1.1 \%$ and $88.6 \%$, indicating that some companies have more appropriate level of debt and risk control, some companies are subject to higher debt pressure and greater operational risk. In general, different companies have different consistency in different indicators, but from the standard deviation point of view, the difference is more obvious.

\subsection{Model Inspection and Selection}

\subsubsection{Correlation Test}

The correlation between two variables can be calculated by Pearson test. It is generally believed that the absolute value of the Pearson coefficient is less than 0.1 belongs to the low correlation, in the range of 0.1 to 0.3 is moderate correlation, more than 0.5 is highly correlated. The Pearson coefficients of the Expected Investment Model are shown in Table 2. The absolute value of the Pearson coefficient between variables are almost less than 0.5 , indicating that there is no serious collinearity.

Table 2. Pearson test results for the Expected Investment Model

\begin{tabular}{|c|c|c|c|c|c|c|c|}
\hline & Growth $_{\mathrm{i}, \mathrm{t}-1}$ & $\operatorname{Lev}_{i, t-1}$ & $\operatorname{Cash}_{\mathrm{i}, \mathrm{t}-1}$ & Age $_{i, t-1}$ & Size $_{i, t-1}$ & $\operatorname{Ret}_{i, t-1}$ & $\mathrm{I}_{\mathrm{i}, \mathrm{t}-1}$ \\
\hline Growth $_{\mathrm{i}, \mathrm{t}-1}$ & 1 & & & & & & \\
\hline \multirow[t]{2}{*}{$\operatorname{Lev}_{\mathrm{i}, \mathrm{t}-1}$} & -0.028 & 1 & & & & & \\
\hline & 0.2585 & & & & & & \\
\hline \multirow[t]{3}{*}{$\operatorname{Cash}_{i, t-1}$} & 0.083 & -0.607 & 1 & & & & \\
\hline & $* * *$ & $* * *$ & & & & & \\
\hline & 0.0009 & 0.0000 & & & & & \\
\hline \multirow[t]{3}{*}{$\operatorname{Age}_{\mathrm{i}, \mathrm{t}-1}$} & -0.107 & 0.193 & -0.411 & 1 & & & \\
\hline & $* * *$ & $* * *$ & $* * *$ & & & & \\
\hline & 0.0000 & 0.0000 & 0.0000 & & & & \\
\hline \multirow[t]{3}{*}{ Size $_{i, t-1}$} & -0.028 & 0.313 & -0.216 & 0.396 & 1 & & \\
\hline & & $* * *$ & $* * *$ & $* * *$ & & & \\
\hline & 0.2562 & 0.0000 & 0.0000 & 0.0000 & & & \\
\hline \multirow[t]{3}{*}{$\operatorname{Ret}_{\mathrm{i}, \mathrm{t}-1}$} & -0.038 & 0.150 & -0.133 & 0.288 & 0.054 & 1 & \\
\hline & & $* * *$ & $* * *$ & $* * *$ & $*$ & & \\
\hline & 0.1879 & 0.0000 & 0.0000 & 0.0000 & 0.0617 & & \\
\hline \multirow[t]{3}{*}{$\mathrm{I}_{\mathrm{i}, \mathrm{t}-1}$} & -0.184 & 0.228 & -0.543 & 0.242 & 0.039 & -0.032 & 1 \\
\hline & $* * *$ & $* * *$ & $* * *$ & $* * *$ & & & \\
\hline & 0.0000 & 0.0000 & 0.0000 & 0.0000 & 0.1119 & 0.2791 & \\
\hline
\end{tabular}

Note: $* * *, * *, *$ are indicated at $1 \%, 5 \%, 10 \%$, respectively

There exists absolute value of Pearson coefficients greater than 0.5 , so test the variance expansion factor (VIF) value for further inspection. It is generally assumed that if VIF value is between 1 and 10, there is no serous multiple collinearity. As can be seen from Table 3, the VIF values of the variables and the VIF mean belong to the absence of serious multiple collinearity. Therefore, it is determined that there is no serious multicollinearity in the Expected Investment Model. 
Table 3. Variance expansion factor of the Expected Investment Model

\begin{tabular}{ccccccccc}
\hline $\begin{array}{c}\text { Variables } \\
\text { name }\end{array}$ & Cash $_{\mathrm{i}, \mathrm{t}-1}$ & Lev $_{\mathrm{i}, \mathrm{t}-1}$ & $\mathrm{I}_{\mathrm{i}, \mathrm{t}-1}$ & Age $_{\mathrm{i}, \mathrm{t}-1}$ & Size $_{\mathrm{i}, \mathrm{t}-1}$ & Ret $_{\mathrm{i}, \mathrm{t}-1}$ & Growth $_{\mathrm{i}, \mathrm{t}-1}$ & $\begin{array}{c}\text { VIF } \\
\text { mean }\end{array}$ \\
\hline $\begin{array}{c}\text { VIF } \\
\text { value }\end{array}$ & 2.13 & 1.78 & 1.45 & 1.31 & 1.29 & 1.12 & 1.06 & 1.45 \\
\hline
\end{tabular}

\subsubsection{Heteroscedasticity Test}

Panel data heteroskedasticity can be derived from the Waldorf test, Waldorf test hypothesis "Different individual perturbation variance are equal." The test results are shown in Table 4. From the P value, we can see that the test results strongly reject the original hypothesis, and that there are heteroskedasticity, so we use the White estimation to eliminate the heteroscedasticity when introducing the regression.

Table 4. Ward test results for the Expected Investment Model

\begin{tabular}{ccc}
\hline Statistics & Statistical value & P value \\
\hline Chi2 (355) & $4.7 \mathrm{e}+33$ & 0.0000 \\
\hline
\end{tabular}

\subsubsection{Model Selection}

First use the BP Lagrangian multiplier test to determine whether to use mixed regression, BP Lagrangian multiplier test hypothesis "model does not exist individual effect." Test results shown in Table 5, by the $\mathrm{P}$ value shows that the test results rejected the original hypothesis, that there are individual effects.

Table 5. Expected Investment Model BP Lagrange multiplier test results

\begin{tabular}{ccc}
\hline Statistics & Statistical value & P value \\
\hline Chibar2 $(01)$ & 5.12 & 0.0118 \\
\hline
\end{tabular}

Individual effects need to be further determined whether the random effect model or the fixed effect model is selected, so enter the Hausman test. The Hausman test assumes that "Individual effects are random". Test results shown in Table 6, from the $\mathrm{P}$ value shows that the test results strongly rejected the original hypothesis, so select fixed effect model.

Table 6. Hausman test results for the Expected Investment Model

\begin{tabular}{ccc}
\hline Statistics & Statistical value & P value \\
\hline Chi2 $(7)$ & 275.77 & 0.0000 \\
\hline
\end{tabular}

\subsubsection{Autocorrelation Test}

When select the GMM for dynamic unbalanced panel, the first step is to verify the validity of this method as a consensus estimate before the reunification. This is done by the Arellano-Bond test to detect whether there is a first order and second order autocorrelation for the difference of the perturbation term. Test results shown in Table 7, $\mathrm{P}$ value shows the presence of a differential disturbance order autocorrelation, there is no second order autocorrelation, so accept the null hypothesis "disturbance term $\left|\varepsilon_{\mathrm{i}, \mathrm{t}}\right|$ is no autocorrelation" which means the GMM is valid.

Table 7. Autocorrelation test results for the Expected Investment Model

\begin{tabular}{ccc}
\hline Order & Z value & P value \\
\hline First order & -2.5992 & 0.0093 \\
Second order & -1.6225 & 0.1047 \\
\hline
\end{tabular}




\subsection{Return Results and Inefficient Investment Degree}

\subsubsection{Regression Results}

The GMM method is used to return the Expected Investment Model. The empirical results are shown in Table 8.

Table 8. Regression results for the Expected Investment Model

\begin{tabular}{cccc}
\hline Variable name & $\begin{array}{c}\text { Regression } \\
\text { coefficient }\end{array}$ & Z value & P value \\
\hline Growth $_{\mathrm{i}, \mathrm{t}-1}$ & 0.010 & 2.28 & 0.023 \\
Lev $_{\mathrm{i}, \mathrm{t}-1}$ & -0.283 & -3.71 & 0.000 \\
Cash $_{\mathrm{i}, \mathrm{t}-1}$ & 0.212 & 2.78 & 0.005 \\
Age $_{\mathrm{i}, \mathrm{t}-1}$ & -0.622 & -3.64 & 0.000 \\
Size $_{\mathrm{i}, \mathrm{t}-1}$ & 0.135 & 3.9 & 0.000 \\
Ret $_{\mathrm{i}, \mathrm{t}-1}$ & 0.002 & 0.39 & 0.696 \\
$\mathrm{I}_{\mathrm{i}, \mathrm{t}-1}$ & 1.015 & 4.48 & 0.000 \\
Intercept & -2.793 & -3.66 & 0.000 \\
\hline Industry Dummy & & control & \\
Year Dummy & & control & \\
$\mathrm{N}$ & & 823 & \\
Wald chi2 (10) & & 67.400 & \\
Prob $>$ chi2 & & 0.0000 & \\
\hline
\end{tabular}

From Table 8 , we can see that the model is very significant and the explanatory ability is very strong. The new investment amount in this year is positively correlated with the growth opportunity, the cash holding amount, the firm size and the new investment amount in the previous year. The asset-liability ratio, the number of years of listing has a significant negative correlation with the company's stock returns have a positive correlation, but not significant.

Specifically, part of the company's new asset investment is a multi-period continuous investment process, there will be increased investment this year because the increase investment last year. If the growth of the company is better, long-term asset investment will increase the scale for taking the long-term development strategy into account; the other hand, if the company is in a poor growth trend, it is more likely to reduce long-term asset investment scale to allocate funds to existing businesses, resulting in a decrease in new investment in the current period. The higher cash holdings, indicating higher cash liquidity and operating turnover. In this case, there are stronger motivations and conditions to invest. The greater the size of the company, it is easier to obtain high-quality project opportunities, which will promote the company to invest in large projects. The higher the level of corporate debt, the greater the risk of debt and operating risks faced by them, and the risk aversion in the course of investments, especially long-term investments, which will reduce the level of investment this year.

\subsubsection{Inefficient Investment Degree}

Descriptive statistics on inefficient investments are shown in Table 9:

Table 9. Descriptive statistics of inefficient investments

\begin{tabular}{cccccc}
\hline Variable name & Observations & Average value & $\begin{array}{c}\text { Minimum } \\
\text { value }\end{array}$ & $\begin{array}{c}\text { Maximum } \\
\text { value }\end{array}$ & $\begin{array}{c}\text { Standard } \\
\text { deviation }\end{array}$ \\
\hline $\mathrm{OI}_{\mathrm{i}, \mathrm{t}}$ & 638 & 0.421 & 0.008 & 1.250 & 0.304 \\
$\mathrm{UI}_{\mathrm{i}, \mathrm{t}}$ & 540 & 0.497 & 0.000 & 1.159 & 0.285 \\
\hline
\end{tabular}


As can be seen from the results of Table 9, there are 1178 observations of inefficient investment, of which $54.16 \%$ are over-invested, and the average degree was 0.421 ; there were 540 observations, accounting for $45.84 \%$, and the average degree of underinvestment was 0.497 .

\section{Research Conclusions and Outlook}

\subsection{Conclusions}

Based on the Principal-agent theory and Information Asymmetry Theory combined with Free Cash Flow Hypothesis and Financing Constraint Hypothesis, this paper made a theoretical review of the causes of inefficient investment behavior. On this basis, this paper used residual of the Expected Investment Model to measure the degree of inefficient investment, from 2010 to 2015. The result is nearly half observation of the GEM listed companies have inefficient investment behavior, and there is no obvious bias between overinvestment and underinvestment.

This paper measured the level of inefficient investment of listed companies on the GEM, so that the micro-subject in the multi-level capital market can clearly define the direction of its own need. In addition, we also hope to provide empirical reference for the policy makers in the formulation of relevant policies to create a good market environment for listed companies.

\subsection{Outlook}

At present, the research on the investment efficiency of listed companies is less involved in the GEM listed companies. Therefore, this paper is an exploration of the field. The future research can expand to how to increase the investment efficiency of the GEM listed companies. At the same time with the continued development of the GEM, the sample can be studied will increasing. There will be able to carry out more in-depth and comprehensive empirical analysis for the sustained and healthy development of capital markets to provide theoretical support and empirical data.

\section{References}

Akerlof, G. A. (1970). The Market for "Lemons": Quality Uncertainty and the Market Mechanism. Quarterly Journal of Economics, 84(3), 488-500. https://doi.org/10.2307/1879431

Bebchuk, L. A., \& Stole, L. A. (1993). Do Short-Term Objectives Lead to Under- or Overinvestment in $\begin{array}{lllll}\text { Long-Term Projects?. The Journal of Finance, 48(2), } & \text { 719-729. }\end{array}$ https://doi.org/10.1111/j.1540-6261.1993.tb04735.x

Berle, A. A., \& Means, G. C. (1932). The Modern Corporation and Private Property. Macmillan.

Cleary, S. (1999). The Relationship between Firm Investment and Financial Status. The Journal of Finance, 54(2), 673-692. https://doi.org/10.1111/0022-1082.00121

Dong, H. (2009). Major shareholder control and accounting conservatism-Empirical test from Chinese A-share listed companies. Journal of Shanxi University of Finance and Economics, (1), 117-124.

Fazzari, S. M., \& Petersen, B. C. (1993). Working Capital and Fixed Investment: New Evidence on Financing Constraints. RAND Journal of Economics, 24(3), 328-342. https://doi.org/10.2307/2555961

Fazzari, S. M., Hubbard, R. G., \& Petersen, B. C., et. al. (1988). Financing Constraints and Corporate Investment. Brookings Papers on Economic Activity, (1), 141-206. https://doi.org/10.2307/2534426

Gilchrist, S., \& Himmelberg, C. P. (1995). Evidence on the role of cash flow for investment. Journal of Monetary Economics, 36(3), 541-572. https://doi.org/10.1016/0304-3932(95)01223-0

Grenadier, S. R., \& Wang, N. (2006). Investment under uncertainty and time-inconsistent preferences. Journal of Financial Economics, 84(1), 2-39. https://doi.org/10.1016/j.jfineco.2006.01.002

Heinkel, R., \& Zechner, J. (1990). The Role of Debt and Preferred Stock as a Solution to Adverse Investment Incentives. Journal of Financial and Quantitative Analysis, 25(1), 1-24. https://doi.org/10.2307/2330885

Hirshleifer, D., \& Thakor, A. V. (1992). Managerial Conservatism, Project Choice, and Debt. Review of Financial Studies, 5(3), 437-470. https://doi.org/10.1093/rfs/5.3.437

Jensen, M. C. (1986). Agency Costs of Free Cash Flow, Corporate Finance, and Takeovers. American Economic Review, 76(2), 323-329.

Jensen, M. C., \& Meckling, W. H. (1976). Theory of the firm: Managerial behavior, agency costs and ownership $\begin{array}{lllll}\text { structure. Social Science Electronic Publishing, 305-360. } & \text { 3(4), }\end{array}$ https://doi.org/10.1016/0304-405x(76)90026-x 
Kaplan, S. N., \& Zingales, L. (1997). Do Investment-Cash Flow Sensitivities Provide Useful Measures of Financing Constraints?". Quarterly Journal of Economics, 112(1), 169-215. https://doi.org/10.1162/003355397555163

Liu, C. (2006). Corporate governance mechanism, free cash flow and overinvestment behavior of listed companies. Economic Sciences, (4), 50-58.

Liu, H., \& Ouyang, L. (2004). Manager of private interests and overinvestment. System Engineering Theory and Practice, (10), 44-48.

Liu, X., Liu, L., \& Dou, W. (2014). Study on Financing Constraint, Agent Conflict and Inferior Investment Behavior of Chinese Listed Companies. Journal of Management Science, (3), 64-73.

Moyen, N. (2004). Investment-Cash Flow Sensitivities: Constrained versus Unconstrained Firms. The Journal of Finance, 59(5), 2061-2092. https://doi.org/10.1111/j.1540-6261.2004.00692.x

Murphy, K. J. (1985). Corporate performance and managerial remuneration: An empirical analysis. Journal of Accounting and Economics, 7(1-3), 11-42. https://doi.org/10.1016/0165-4101(85)90026-6

Myers, S. C., \& Majluf, N. S. (1984). Corporate financing and Investment decisions when firms have information that Investors do not have. Journal of Financial Economics, 13(2), 187-221. https://doi.org/10.1016/0304-405X(84)90023-0

Narayanan, M. P. (1987). Managerial Incentives for Short-Term Results. The Journal of Finance, 40(4), 1469-1484. https://doi.org/10.1111/j.1540-6261.1987.tb03933.x

Narayanan, M. P. (1988). Debt Versus Equity under Asymmetric Information. Journal of Financial and Quantitative Analysis, 23(1), 39-51. https://doi.org/10.2307/2331023

Noe, T. H., \& Rebello, M. J. (1997). Renegotiation, Investment Horizons, and Managerial Discretion. Journal of Business, 70(3), 385-407. https://doi.org/10.1086/209723

Ouyang, L., Ouyang, L., \& Zhou, H. (2005). Equity system arrangement, information asymmetry and enterprise inefficient investment behavior. Contemporary Economic Science, (4), 72-78, 111.

Richardson, S. (2006). Overinvestment of free cash flow. Review of Accounting Studies, 11(2), 159-189. https://doi.org/10.1007/s11142-006-9012-1

Shleifer, A., \& Vishny, R. W. (1989). Management entrenchment: The case of manager-specific Investments. Journal of Financial Economics, 25(1), 123-139. https://doi.org/10.1016/0304-405X(89)90099-8

Spence, M. (1973). Job Market Signaling. Quarterly Journal of Economics, 87(3), 355-374. https://doi.org/10.2307/1882010

Stiglitz, J. E., \& Weiss, A. (1981). Credit Rationing in Markets with Imperfect Information. American Economic Review, 71(3), 393-410.

Stulz, R. (1990). Managerial discretion and optimal financing policies. Journal of Financial Economics, 26(1), 3-27. https://doi.org/10.1016/0304-405X(90)90011-N

Tang, X., Zhou, X., \& Ma, R. (2010). Government intervention, GDP growth and overinvestment of local state-owned enterprises. Finance Research, (8), 33-48.

Vogt, S. C. (1994). The Cash Flow-Investment Relationship: Evidence from U.S. Manufacturing Firms. Financial Management, 23(2), 3-20. https://doi.org/10.2307/3665735

Wang, S. (2011). An Empirical Study on the Financing Order of Listed Companies - Data from Gansu. Finance and Accounting, (18), 96-99.

Wei, M., \& Liu, J. (2007). State-owned enterprise dividends, governance factors and overinvestment. Management of the World, (4), 88-95.

Wen, S., \& Yang, W. (2003). Investment behavior of short-sighted agents under asymmetric information. Journal of Chongqing University (Natural Science Edition), (7), 135-138

Whited, T. M. (1992). Debt, Liquidity Constraints, and Corporate Investment: Evidence from Panel Data. The Journal of Finance, 47(4), 1425-1460. https://doi.org/10.1111/j.1540-6261.1992.tb04664.x

Xin, Q., Lin, B., \& Wang, Y. (2007). Government control, manager pay and capital investment. Economic Research, (8), 110-122. 
Yang, H., \& Hu, Y. (2007). Institutional environment and excessive investment in free cash flow. Management of the World, (9), 99-106, 116, 172.

Yu, H., Xu, L., \& Chen, Baijia. (2010). Control of ultimate controlling shareholder and excessive cash flow of free cash flow. Economics Research, (8), 103-114.

Yu, X., Jiang, B., \& Li, Y. (2017). The relationship between cash dividend, free cash flow and investment efficiency-Based on the analysis of sample data of listed companies in China's A-share manufacturing industry. Contemporary Economic Research, (1), 80-88.

Zhang, M., Wu, L., \& Wang, Y. (2010). State-owned Equity, Corporate Performance and Investment Behavior. Finance Research, (12), 115-130.

Zhao, H., Jia, D., \& Pan, L. (2010). Research on the Relationship between Managerial Management Defense and Enterprise Inefficient Investment-An Empirical Study from Listed Companies in Anhui Province. Finance and Banking News, (33), 75-78.

\section{Copyrights}

Copyright for this article is retained by the author(s), with first publication rights granted to the journal.

This is an open-access article distributed under the terms and conditions of the Creative Commons Attribution license (http://creativecommons.org/licenses/by/4.0/). 